\title{
PENGARUH KINERJA KEUANGAN, STRUKTUR MODAL, DAN TATA KELOLA PERUSAHAAN TERHADAP NILAI PERUSAHAAN PADA PERUSAHAAN SEKTOR BARANG KONSUMSI YANG TERDAFTAR DI BEI
}

\author{
Linda Rosalina ${ }^{1}$, Hairunnisa ${ }^{2}$, Annisa ${ }^{3}$, Annisa Izzati Islam ${ }^{4}$, Farah Margaretha Leon ${ }^{5}$ \\ Fakultas Ekonomi dan Bisnis Universitas Trisakti \\ Jalan Kyai Tapa No 1 Grogol Jakarta \\ Farahmargaretha@trisakti.ac.id
}

\begin{abstract}
This research aims to determine whether financial performance, capital structure, and corporate governance can affect the value of the company. The independent variables in this study are financial performance, capital structure, and corporate governance, while the dependent variable is firm value. This study collects data from 21 consumer goods sector companies listed on the Indonesia Stock Exchange with a research period during 20162020 and uses multiple regression models for testing. The findings of this study indicate that financial performance as measured by sales growth and revenue growth, rate of return on assets (ROA), capital structure and corporate governance as measured by ownership structure, managerial ownership, and independent commissioners have no effect on firm value. Meanwhile, corporate governance as measured by the board of directors, institutional ownership, audit committee, and board of commissioners has a significant effect on firm value. The results of this study can be used for financial managers in making decisions that will further increase the value of the company and for investors to pay attention to what components must be considered when assessing which company to choose to invest. In the novelty of this study, independent commissioners and commissioners were added to measure the independent variable, namely corporate governance so that the measurement could be distinguished from previous studies.
\end{abstract}

Keywords: Capital structure, corporate governance, financial performance, firm value.

\begin{abstract}
Abstrak
Penelitian ini bertujuan untuk menentukan apakah kinerja keuangan, struktur modal, dan tata kelola perusahaan benar-benar dapat mempengaruhi nilai perusahaan tersebut. Variabel independen dalam penelitian ini adalah kinerja keuangan, struktur modal, dan tata kelola perusahaan sedangkan variabel dependennya adalah nilai perusahaan. Studi ini mengumpulkan data dari 21 perusahaan sektor barang konsumsi yang terdaftar di Bursa Efek Indonesia dengan periode penelitian 5 tahun (2016-2020) dan menggunakan model regresi berganda untuk pengujiannya. Temuan dari penelitian ini menunjukkan bahwa kinerja keuangan yang diukur dengan pertumbuhan penjualan dan pertumbuhan pendapatan, tingkat pengembalian aset (ROA), struktur modal serta tata kelola perusahaan yang di ukur dengan struktur kepemilikan, kepemilikan manajerial, dan komisaris independen tidak memiliki pengaruh terhadap nilai perusahaan. Sedangkan tata kelola perusahaan yang di ukur dengan dewan direksi, kepemilikan institusional, komite audit, dan dewan komisaris berpengaruh signifikan terhadap nilai perusahaan. Hasil penelitian ini dapat digunakan bagi manajer keuangan dalam pengambilan keputusan yang akan lebih meningkatkan nilai perusahaan dan bagi investor untuk memperhatikan komponen apa saja yang harus diperhatikan saat menilai perusahaan mana yang akan dipilih untuk berinvestasi. Dalam kebaruan studi ini, dewan komisaris dan komisaris independen ditambah untuk mengukur variabel independen yaitu tata kelola perusahaan agar pengukuran bisa dibedakan dari penelitian-penelitian sebelumnya.
\end{abstract}

Kata kunci: Kinerja keuangan; nilai perusahaan; struktur modal; tata kelola perusahaan.

Pendahuluan
Investasi menjadi tren di Indonesia dengan ditandai jumlah investor di Indonesia 
yang meningkat setiap tahunnya. Berdasarkan pada data Otoritas Jasa Keuangan (OJK), jumlah investor pasar modal tercatat sudah mencapai 4,51 juta pada akhir buan Februari 2021. Kenaikan ini dapat dibilang cukup tinggi jika dibandingkan dengan jumlah investor pasar modal yang tercatat di OJK pada bulan Desember 2020, yakni sebesar 3,88 juta investor. Dalam jangka waktu hanya dua bulan, jumlah investor pasar modal telah mengalami peningkatan sebesar 16,24\% https: //investasi.kontan.co.id. Meningkatnya investor menjadikan perusahaan fokus pada bagaimana cara untuk meningkatkan nilai perusahaan demi mendapatkan investasi dari para investor tersebut. Pada umumnya, investor cenderung memiliki pandangan bahwa tingkat keberhasilan sebuah perusahaan dapat tercermin pada nilai perusahaannya, dimana sering dikaitkan dengan harga saham perusahaan tersebut. Sebuah perusahaan yang memiliki nilai saham yang tinggi maka tinggi juga nilai perusahaan yang dimilikinya. Pasar akan percaya pada perusahaan yang memiliki nilai perusahaan tinggi bahwa kinerja keuangan perusahaan saat ini baik dan juga perusahaan memiliki prospek di masa yang akan datang. Memaksimalkan kemakmuran pemegang saham merupakan tujuan utama sebuah perusahaan dan memiliki arti yang penting, karena dengan itu maka perusahaan dapat memaksimalkan nilai perusahaan (Irawan \& Nurhadi, 2019).

Nilai perusahaan akan menjadi pandangan atau patokan para investor pada keberhasilan suatu perusahaan dalam mengelola sumber dayanya. Saham yang semakin banyak diminati oleh investor maka akan meningkatkan harga saham tersebut seperti berlakunya hukum permintaan dan penawaran. Hal ini akan memberikan efek domino bagi perusahaan, yaitu setelah kenaikan harga saham selanjutnya nilai perusahaan juga akan ikut meningkat. Pergerakan harga saham naik atau turun akan sangat menentukan posisi perusahaan di kalangan para investor (Lesmana et al., 2020). Analisa laporan keuangan seringkali digunakan untuk mengetahui bagaimana kinerja keuangan perusahaan dalam suatu periode pelaporan. Kondisi sehat atau tidak sehatnya sebuah perusahaan memiliki kaitan erat dengan kinerja keuangan perusahaan tersebut. Kinerja keuangan yang buruk mencerminkan kondisi perusahaan yang tidak sehat diikuti dengan nilai perusahaan yang menurun, sebaliknya jika kinerja keuangan perusahaan baik maka kondisi perusahaan tersebut sehat dan akan meningkatkan nilai perusahaan. Perusahaan yang memiliki nilai perusahaan tinggi tersebut akan memiliki harga saham yang tinggi juga karena investor lebih memilih untuk berinvestasi pada perusahaan yang memiliki nilai perusahaan tinggi. Perusahaan yang memiliki kinerja keuangan yang tidak sehat menyebabkan harga sahamnya menurun (Irawan \& Nurhadi, 2019)

Tidak hanya nilai perusahaan yang menjadi penting bagi sebuah perusahaan, selain itu ada struktur modal. Sumber modal, besaran porsi sumber tersebut, dan baik buruknya akibat yang muncul dari sumber modal tersebut akan memberikan efek langsung kepada posisi keuangan perusahaan. Struktur modal yang tidak baik seperti perusahaan yang memiliki utang yang sangat besar dimana terdapat ketidakmampuan perusahaan untuk melunasinya merupakan beban berat bagi perusahaan tersebut (Tunggal \& Nagatno, 2018). Dalam literatur keuangan perusahaan juga, telah dikemukakan bahwa peningkatan leverage akan menyebabkan nilai perusahaan meningkat (Talwar, 2020).

Faktor lainnya yang dapat mempengaruhi nilai perusahaan adalah tata kelola perusahaan. Meningkatnya nilai perusahaan dapat tercermin pada perusahaan yang melakukan tata kelola perusahaan dengan baik dengan menerapkan prinsip good corporate governance (GCG). Investor lebih tertarik pada perusahaan yang dapat menerapkan komitmen GCG dengan baik karena prinsipnya yang transparan, kredibel, independen, dan akuntabel. Perusahaan harus memiliki mekanisme dan prosedur yang tepat agar setiap lini anggota perusahaan dapat menjalankan tugas, fungsi, serta tanggungjawabnya untuk kepentingan perusahaan, demi terwujudnya tata kelola yang baik. Prinsip yang dimikiki GCG diharapkan mampu diterapkan dengan baik oleh perusahaan sehingga dapat meningkatkan nilai perusahaan (Jamaluddin et al., 2020).

Penelitian ini memiliki tujuan untuk menentukan apakah kinerja keuangan, struktur 
modal, dan tata kelola perusahaan benar-benar dapat mempengaruhi nilai perusahaan. Penelitian ini memiliki kebaruan yaitu menggunakan proksi tambahan dewan komisaris dan komisaris independen untuk variabel tata kelola perusahaan. Dalam pengambilan keputusan perusahaan wajar jika terdapat perbedaan pendapat diantara manajer, namun diperlukan pihak luar dari perusahaan yang bertindak sebagai penengah. Penengah diperlukan agar tidak sampai terjadi konflik di dalam perusahaan juga sebagai kontrol para manajer sehingga manajemen perusahaan dapat berjalan baik. Fungsi tersebut merupakan tugas komisaris independen, sehingga dapat dikatakan komisaris independen juga dapat mempengaruhi nilai perusahaan (Jamaluddin et al., 2020). Sample yang digunakan dalam penelitian adalah perusahaan yang termasuk kedalam sektor barang konsumsi yang telah terdaftar di Bursa Efek Indonesia (BEI). Sektor barang konsumsi dipilih karena perusahaanperusahaan didalamnya lebih dikenal oleh masyarakat luas karena produknya yang sering digunakan untuk keperluan sehari-hari.

\section{Nilai Perusahaan}

Investor tidak asal memilih perusahaan untuk berinvestasi. Aspek utama yang dilihat oleh investor yakni nilai perusahaan. Nilai perusahaan yang meningkat dari tahun ke tahun menjadi sebuah cerminan bahwa perusahaan berhasil dalam menjalankan usahanya. Nilai perusahaan juga dapat mencerminkan kemakmuran pemegang sahamnya, jika nilai perusahaan meningkat maka pemegang saham juga semakin makmur. Oleh karena itu, menjadi hal yang penting untuk meningkatkan nilai perusahaan karena dengan meningkatnya nilai perusahaan maka kemakmuran pemegang saham meningkat dan investor lain pun juga akan tertarik pada perusahaan tersebut. Semakin banyaknya investor yang tertarik pada saham suatu perusahaan, maka harga saham perusahaan tersebut juga akan ikut meningkat (Arifianto \& Chabachib, 2016).

\section{Kinerja Keuangan}

Perusahaan memiliki sasaran, tujuan, misi, dan visi yang diwujudkan dengan startegic planning. Pelaksanaan perencanaan harus dievaluasi dan dinilai apakah telah tercapai, terdapat masalah, atau terdapatt kekurangan baik pada perencanaan maupun pelaksanaan. Dalam aspek keuangan, kinerja keuangan menjadi gambaran bagaimana kondisi keuangan perusahaan dalam suatu periode tertentu yang tertuang dalam laporan keuangan perusahaan. Kinerja keuangan dapat diukur dengan menilai dan menganalisis laporan keuangan. Analisis rasio keuangan dilakukan untuk mengevaluasi bagaimana kondisi suatu perusahaan pada periode tertentu (Nursani, 2020). Variabel kinerja keuangan dalam penelitian ini diukur dengan menggunakan pertumbuhan penjualan, pertumbuhan pendapatan, dan ROA.

Berdasarkan penelitian sebelumnya yang dilakukan oleh Talwar, (2020) menemukan bahwa pengukuran kinerja keuangan, yaitu pertumbuhan penjualan berpengaruh positif signifikan terhadap nilai perusahaan. Pertumbuhan pendapatan memiliki hubungan negatif terhadap nilai perusahaan. Selanjutnya, ROA memiliki hubungan positif signifikan terhadap nilai perusahaan untuk sektor-sektor yang dipilih. Hasil ini sejalan dengan temuan penelitian lain yaitu Asiri \& Hameed, (2014).

\section{Struktur Modal}

Terdapat teori mengenai struktur modal, yaitu trade off theory. Teori tersebut mengatakan bahwa rasio-rasio utang akan menjadi pilihan sumber pendanaan perusahaan bagi manajer untuk meningkatkan nilai perusahaan. Sisi lain dari utang yang meningkat karena dijadikan sumber pendanaan perusahaan adalah bertambahnya juga kewajiban perusahaan yaitu membayar beban bunga pinjaman yang biasanya memiliki jatuh tempo setiap bulan hingga utang dilunasi. Beban bunga yang meningkat menguntungkan bagi perusahaan karena laba menjadi kecil dan pembayaran pajak perusahaan pun menurun. Oleh sebab itu, utang menjadi pilihan utama bagi manajer dalam mempercepat pertumbuhan perusahaan jika dibandingkan dengan sumber pendanaan digunakan dari modal sendiri. Penggunaan modal sendiri tidak berdampak pada pengurangan pajak. Nilai utang perusahaan tetap harus diperhatikan dan 
dikontrol agar kondisi keuangan perusahaan tetap sehat. Struktur modal yang optimal harus dipilih oleh manajer sehingga memiliki biaya modal yang rendah, menghasilkan laba dan nilai perusahaan yang tinggi (Permatasari \& Azizah, 2018).

Berdasarkan teori tersebut, jika perusahaan memiliki struktur modal yang berada pada tingkat lebih tinggi dibandingkan dengan target struktur modal yang optimal, maka setiap penambahan utang hanya akan menurunkan nilai perusahaan. Struktur modal didefinisikan sebagai suatu perbandingan pendanaan jangka panjang perusahaan yang ditunjukkan dengan perbandingan utang jangka panjang terhadap modal sendiri (Utami, 2017). Pengukuran struktur modal dalam penelitian ini diukur dengan leverage dan dividend payout ratio. Rasio leverage mencerminkan perbandingan utang dengan total aset perusahaan, jika leverage tinggi menunjukkan bahwa perusahaan memiliki utang yang lebih tinggi dibandingkan dengan total asetnya. Hal tersebut dapat menurunkan nilai perusahaan. Leverage dapat dikatakan juga sebagai penaksir dari risiko yang melekat pada sebuah perusahaan, jika semakin tinggi maka risiko investasi juga semakin tinggi (Arifianto \& Chabachib, 2016).

Berdasarkan penelitian sebelumnya yang dilakukan oleh Talwar, (2020) menemukan bahwa pengukuran struktur modal dengan leverage \& dividend payout ratio memiliki pengaruh negatif terhadap nilai perusahaan.

\section{Tata Kelola Perusahaan}

Tata kelola perusahaan atau corporate governance merupakan suatu sistem yang terdiri dari sekumpulan struktur, prosedur, dan mekanisme yang dirancang untuk mengelola perusahaan dengan berlandaskan prinsip akuntabilitas yang dapat meningkatkan nilai perusahaan dalam jangka panjang (Kristie Onasis, 2016). Tata kelola perusahaan didefinisikan sebagai sebuah proses yang digunakan oleh seluruh unit dalam perusahaan (pemegang saham, komisaris atau dewan pengawas, direksi, maupun staff) untuk meningkatkan keberhasilan usaha dan akuntabilitas dalam mencapai tujuan bersama dan mewujudkan nilai pemegang saham dengan tetap memperhatikan stakeholder lainnya. Mekanisme tata kelola perusahaan diharapkan dapat meminimalisir konflik keagenan serta mengawasi berjalannya sistem tata kelola perusahaan (Jamaluddin et al., 2020). Berdasarkan penelitian sebelumnya yang dilakukan oleh Talwar, (2020) menemukan bahwa tata kelola perusahaan berpengaruh positif signifikan terhadap nilai perusahaan.

\section{Rerangka Konseptual}

Teori sinyal menunjukkan bahwa terdapat asimetri informasi antara pihak perusahaan sebagai pemilik informasi dengan pihak-pihak yang memerlukan informasi seperti para investor. Oleh karena itu, diperlukan penerbitan laporan keuangan oleh perusahaan sebagai bentuk pemberian informasi kepada pihak-pihak yang berkepentingan (Lesmana et al., 2020). Sinyal yang diberikan diharapkan dapat mempengaruhi pasar secara positif sehingga juga memberikan dampak pada nilai perusahaan. Keberhasilan perusahaan dapat tergambarkan pada meningkatnya nilai perusahaan dari tahun ke tahun. Menurut Arifianto \& Chabachib, (2016) Bagi perusahaan, nilai perusahaan menjadi sangat penting karena meningkatnya nilai perusahaan mencerminkan kemakmuran pemegang saham yang juga meningkat. Pemegang saham yang makmur akan membuat mereka semakin percaya terhadap perusahaan sehingga perusahaan akan mudah mendapatkan investor.

Laporan keuangan yang diberikan perusahaan sebagai suatu informasi dapat mencerminkan kondisi dan posisi keuangan perusahaan tersebut dari kegiatan operasional perusahaan dalam suatu periode pelaporan. Kondisi dan posisi keuangan yang berfluktuatif akan mempengaruhi harga saham perusahaan tersebut, dimana harga saham meruapakan cerminan dari nilai perusahaan yang dimiliki. Investor akan lebih tertarik pada perusahaan yang memiliki kondisi keuangan yang sehat karena mereka percaya akan keberlangsungan hidup perusahaan sehingga mereka tetap mendapatkan keuntungan (Nursani, 2020).

Nilai perusahaan yang baik juga dapat tercipta salah satunya dengan pemilihan struktur modal. Struktur modal yang optimal dengan biaya modal yang rendah harus dipilih oleh perusahaan agar dapat menghasilkan laba 
dan nilai perusahaan yang tinggi (Permatasari \& Azizah, 2018). Tidak cukup dengan apa yang telah dimiliki perusahaan dan kondisi keuangan perusahaan, pengelolaan perusahaan yang baik juga dapat meningkatkan nilai perusahaan. Perusahaan yang memiliki tata kelola perusahaan yang baik, akan mudah dalam mendapatkan dana, mudah dan banyak dikenal berbagai kalangan juga memberikan nilai lebih bagi nama perusahaan yang secara tidak langsung membuat branding atas nama produknya.

Berdasarkan penelitian sebelumnya yang dilakukan oleh Talwar, (2020) menemukan bahwa pengukuran Kinerja Keuangan, yaitu pertumbuhan penjualan berpengaruh positif terhadap nilai perusahaan dan pengaruhnya signifikan. Pertumbuhan pendapatan memiliki hubungan negatif dengan nilai perusahaan. Selanjutnya, ROA memiliki hubungan positif dengan nilai perusahaan. Pengukuran struktur modal dengan leverage berpengaruh positif terhadap nilai perusahaan sedangkan dividend payout ratio berpengaruh negatif dengan nilai perusahaan. tata kelola perusahaan berpengaruh positif dengan nilai. Berdasarkan penjelasan tersebut, rerangka konseptual dalam penelitian ini dapat digambarkan sebagai berikut:

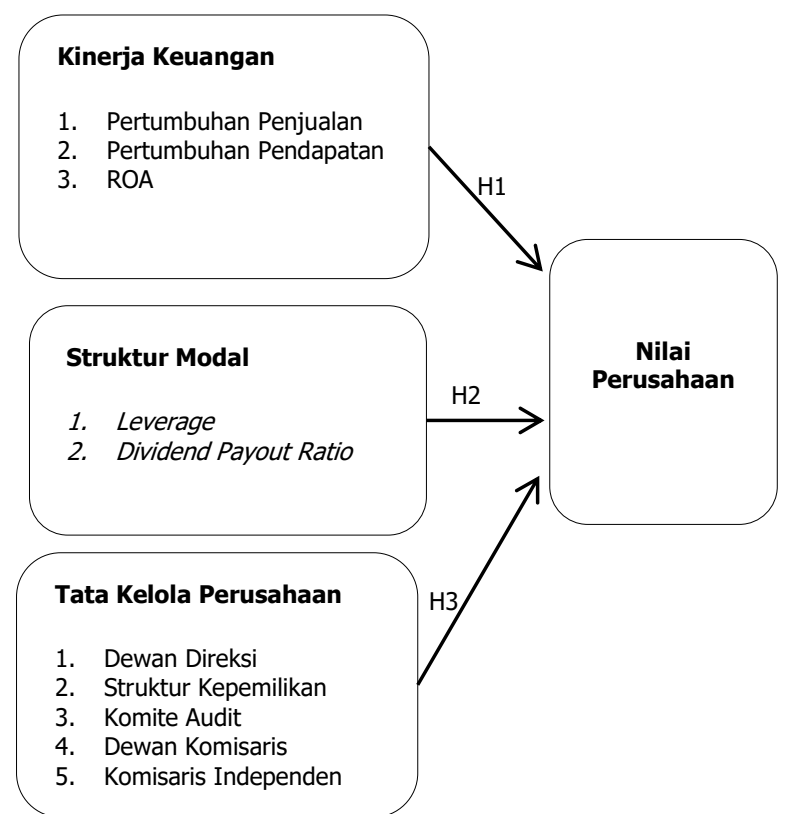

Gambar 1. Bagan Kerangka Pemikiran Pengaruh Kinerja Keuangan, Struktur Modal, dan Tata Kelola Perusahaan terhadap Nilai Perusahaan

\section{Pengembangan Hipotesis}

Rasio laporan keuangan dapat mengetahui apakah sebuah perusahaan berjalan dengan efektif dan efisien yang berpengaruh terhadap peningkatan nilai perusahaan (Lesmana et al., 2020). Hasil penelitian Talwar, S. (2020) menyatakan bahwa pertumbuhan pendapatan memiliki hubungan negatif dengan nilai perusahaan, sedangkan pertumbuhan penjualan dan ROA berpengaruh terhadap positif terhadap nilai perusahaan. Hasil penelitian tersebut juga sesuai dengan hasil penelitian Kumayas et al., (2018) dan Ramadhani et al., (2018) yang menyatakan bahwa kinerja keuangan berpengaruh terhadap nilai perusahaan. Berdasarkan hasil penelitian di atas maka hipotesis disusun sebagai berikut:

\section{$H_{1}$ : Terdapat pengaruh Kinerja Keuangan terhadap Nilai Perusahaan.}

Struktur modal merupakan kombinasi utang dan ekuitas dalam struktur keuangan jangka panjang perusahaan. Struktur modal merupakan masalah yang penting bagi perusahaan karena baik buruknya struktur modal akan mempunyai efek langsung terhadap posisi finansial perusahaan yang pada akhirnya akan mempengaruhi nilai perusahaan (Irawan \& Nurhadi, 2019). Hasil penelitian sebelumnya menunjukkan hasil yang sama dengan pernyataan tersebut Ramadhani et al., (2018), Gayatri \& Mustanda, (2014), Alamsyah \& Muchlas, (2018), dan Talwar, (2020) menyatakan bahwa struktur modal berpengaruh terhadap nilai perusahaan. Berdasarkan hasil penelitian di atas maka hipotesis disusun sebagai berikut:

\section{$\mathrm{H}_{2}$ : Terdapat pengaruh Struktur Modal terhadap Nilai Perusahaan.}

Penerapan tata kelola perusahaan merupakan suatu cara yang dilakukan agar perusahaan dapat mencapai hasil yang bagus dan menghasilkan nilai yang maksimal untuk kepentingan investor serta berpatokan pada undang-undang yang berlaku Mustikowati \& Haryanto, (2019). Penelitian Talwar (2020) membuktikan bahwa govscore berpengaruh terhadap nilai perusahaan. Hasil tersebut juga didukung oleh penelitian Marini \& Marina, (2019) yang menyatakan bahwa dewan komisaris, komisaris independen, dan dewan 
direksi berpengaruh terhadap nilai perusahaan. Berdasarkan hasil penelitian di atas maka hipotesis disusun sebagai berikut:

$\mathrm{H}_{3}$ : Terdapat pengaruh Tata Kelola Perusahaan terhadap Nilai Perusahaan.

\section{Metode Penelitian}

\section{Variabel dan Pengukuran Variabel}

Variabel dalam penelitian ini meliputi variabel dependen, dan variabel independen. Variabel dependennya adalah nilai perusahaan. Variabel independennya kinerja keuangan, struktur modal, dan tata kelola perusahaan. Berikut adalah pengukuran untuk variabel - variabel yang akan diteliti :

\section{Tabel 1}

Identifikasi dan Pengukuran Variabel

\begin{tabular}{|c|c|c|c|c|c|}
\hline $\begin{array}{c}\text { Jenis } \\
\text { Variabel }\end{array}$ & $\begin{array}{c}\text { Nama } \\
\text { Variabel }\end{array}$ & Proxy & Simbol & $\begin{array}{l}\text { Definisi } \\
\text { Variabel } \\
\text { Operasional }\end{array}$ & Referensi \\
\hline Dependen & $\begin{array}{c}\text { Nilai } \\
\text { Perusaha } \\
\text { an }\end{array}$ & Tobins $Q$ & $\begin{array}{c}\text { Tobins } \\
Q\end{array}$ & $\begin{array}{l}\text { Harga saham } \\
\text { penutupan akhir } \\
\text { dikali jumlah } \\
\text { lembar saham } \\
\text { lalu ditambah } \\
\text { total utang dan } \\
\text { setelah itu dibagi } \\
\text { dengan total aset }\end{array}$ & $\begin{array}{l}\text { Tikawati, } \\
\text { T. (2016). }\end{array}$ \\
\hline \multirow{10}{*}{ Independen } & \multirow{3}{*}{$\begin{array}{c}\text { Kinerja } \\
\text { Keuangan }\end{array}$} & $\begin{array}{l}\text { Pertumbuhan } \\
\text { Penjualan }\end{array}$ & PP & $\begin{array}{l}\text { Penjualan tahun } \\
\text { ini dikurangi } \\
\text { penjualan tahun } \\
\text { sebelumnya lalu } \\
\text { dibagi penjualan } \\
\text { tahun } \\
\text { sebelumnya }\end{array}$ & $\begin{array}{l}\text { Kumayas, } \\
\text { et al., } \\
(2018)\end{array}$ \\
\hline & & $\begin{array}{l}\text { Pertumbuhan } \\
\text { Pendapatan }\end{array}$ & ROE & $\begin{array}{l}\text { Laba bersih } \\
\text { setelah pajak } \\
\text { dibagi modal } \\
\end{array}$ & $\begin{array}{l}\text { Arifianto et } \\
\text { al., M. } \\
\text { (2016) }\end{array}$ \\
\hline & & ROA & ROA & $\begin{array}{l}\text { Earning After Tax } \\
\text { dibagi total sset }\end{array}$ & $\begin{array}{l}\text { Lesmana, } \\
\text { et al., } \\
(2020)\end{array}$ \\
\hline & \multirow[b]{2}{*}{$\begin{array}{l}\text { Struktur } \\
\text { Modal }\end{array}$} & Leverage & DER & $\begin{array}{l}\text { Utang jangka } \\
\text { panjang dibagi } \\
\text { modal }\end{array}$ & $\begin{array}{l}\text { Ramadhan } \\
\text { i et al., } \\
\text { (2018) }\end{array}$ \\
\hline & & $\begin{array}{l}\text { Dividend } \\
\text { Payout Ratio }\end{array}$ & DPR & $\begin{array}{l}\text { Dividen per } \\
\text { lembar saham } \\
\text { dibagi laba per } \\
\text { lembar saham }\end{array}$ & $\begin{array}{l}\text { Ramadhan } \\
\text { i et al., } \\
\text { (2018) }\end{array}$ \\
\hline & \multirow{5}{*}{$\begin{array}{c}\text { Tata Kelola } \\
\text { Perusahaa } \\
n\end{array}$} & Dewan Direksi & DD & $\begin{array}{l}\text { Jumlah anggota } \\
\text { dewan direksi }\end{array}$ & $\begin{array}{c}\text { Marini et } \\
\text { al., (2019) }\end{array}$ \\
\hline & & $\begin{array}{c}\text { Struktur } \\
\text { Kepemilikan }\end{array}$ & $\begin{array}{l}\text { KINST } \\
\& \text { KM }\end{array}$ & $\begin{array}{l}\text { KI = Jumlah } \\
\text { Saham Institusi } \\
\text { dibagaii total } \\
\text { saham beredar } \\
\text { dikali } 100 \% \\
\text { KM = Jumlah } \\
\text { saham } \\
\text { manajerial dibagi } \\
\text { total saham } \\
\text { beredar dikali } \\
100 \% \\
\end{array}$ & $\begin{array}{l}\text { Wibowo, } \\
\text { S. (2015) } \\
\text { Hunardy et } \\
\text { al., (2017) }\end{array}$ \\
\hline & & Komite Audit & $\mathrm{KA}$ & $\begin{array}{l}\text { Jumlah anggota } \\
\text { komite audit }\end{array}$ & $\begin{array}{c}\text { Marini et } \\
\text { al., (2019) }\end{array}$ \\
\hline & & $\begin{array}{c}\text { Dewan } \\
\text { Komisaris } \\
\end{array}$ & DK & $\begin{array}{l}\text { Jumlah anggota } \\
\text { dewan komisaris }\end{array}$ & $\begin{array}{c}\text { Marini et } \\
\text { al., }(2019) \\
\end{array}$ \\
\hline & & $\begin{array}{l}\text { Komisaris } \\
\text { Independen }\end{array}$ & KINDP & $\begin{array}{l}\text { Jumlah komisaris } \\
\text { independen } \\
\text { dibagi jumlah } \\
\text { anggota dewan } \\
\text { komisaris }\end{array}$ & $\begin{array}{c}\text { Marini et } \\
\text { al., (2019) }\end{array}$ \\
\hline
\end{tabular}

\section{Metode Pengambilan Sampel}

Pengumpulan data sekunder merupakan metode pengumpulan data yang digunakan dengan cara memperoleh data yang sudah ada baik dari penelitian maupun laporan yang diterbitkan oleh perusahaan. Populasi data penelitian ini terdiri dari seluruh perusahaan yang berada di sektor barang konsumsi yang sudah listing di Bursa Efek Indonesia, yaitu berjumlah 36 perusahaan. Perusahaan yang dijadikan sample yang memenuhi kriteria berjumlah 21 perusahaan. Total tersebut dan kriteria pengambilan data sample dijabarkan dalam tabel sebagai berikut:

Tabel 2

Kriteria Pengambilan Sampel

\begin{tabular}{|lc|}
\hline \multicolumn{1}{|c|}{ Keterangan } & $\begin{array}{c}\text { Jumlah } \\
\text { Perusahaan }\end{array}$ \\
\hline $\begin{array}{l}\text { Perusahaan sektor barang } \\
\text { konsumsi yang terdaftar di } \\
\text { BEI selama periode } 2016- \\
2020\end{array}$ & 36 \\
\hline $\begin{array}{l}\text { Perusahaan yang tidak } \\
\text { mempublikasikan laporan } \\
\text { keuangan tahunan secara } \\
\text { berturut-turut selama periode } \\
\text { 2016 - 2020 }\end{array}$ & $(5)$ \\
\hline $\begin{array}{l}\text { Perusahaan yang merugi } \\
\text { selama tahun pengamatan }\end{array}$ & $(10)$ \\
\hline Total Sampel & 21 \\
\hline $\begin{array}{l}\text { Jumlah Pengamatan } \\
\text { (Pengamatan selama 5 tahun) }\end{array}$ & 105 \\
\hline
\end{tabular}

Terdapat beberapa tahapan pengujian model regresi dalam penelitian ini, yaitu antara lain :

\section{Uji Chow Test}

Uji ini merupakan salah satu uji untuk memilih model terbaik pada regresi data panel. Uji ini bertujuan untuk memilih model terbaik antara dua mode, yaitu model fixed effect dengan model common effect. Kriteria pengambilan keputusannya yaitu jika nilai probabilitas cross section dari chi square $<0,05$ maka model yang terbaik adalah model fixed effect.

\section{Uji Hausman Test}

Uji ini juga merupakan salah satu uji untuk memilih model terbaik pada regresi data panel yang dilakukan setelah uji chow test dijalankan. Uji ini memilih model terbaik antara model fixed effect dengan model random effect. Kriteria pengambilan keputusannya yaitu jika nilai probabilitas cross section dari random $<0,05$ maka model yang terbaik adalah model fixed effect. 
Berdasarkan tabel 3 hasil uji chow test dan hausman test menunjukkan bahwa nilai probabilitas cross section dari chi square sebesar 0,000<0,05 sehingga keputusan yang diambil adalah $\mathrm{H}_{0}$ ditolak. Model yang baik digunakan adalah model fixed effect. Setelah model fixed effect terpilih maka dilakukan uji selanjutnya yaitu uji hausman test. Tabel 3 menunjukkan hasil probabilitas cross section dari random sebesar 0,000 $<0,05$ sehingga keputusan yang diambil adalah $\mathrm{H}_{0}$ ditolak. Kesimpulannya adalah model fixed effect merupakan model yang baik untuk digunakan dalam penelitian ini.

Tidak selamanya kedua uji tersebut diterapkan hasilnya dalam pemilihan model fixed effect atau random effect. Pemilihan model terbaik juga dapat dilakukan dengan mempertimbangkan jumlah waktu dan total sample yang dimiliki pada sebuah penelitian. Beberapa ahli ekonometri telah membuktikan secara matematis bahwa jika data panel yang dimiliki mempunyai jumlah waktu ( $T$ ) lebih kecil dibandingkan dengan jumlah individu atau sample (N) maka disarankan untuk menggunakan model random effect (Sakti, 2018). Oleh karena itu, penelitian ini menggunakan model random effect karena jumlah waktu 5 tahun lebih sedikit dibandingkan dengan jumlah individu atau jumlah sample yaitu 21 perusahaan.

Tabel 3

Hasil Uji Chow Test dan Uji Hausman Test

\begin{tabular}{|cccc|}
\hline $\begin{array}{c}\text { Test } \\
\text { Summary }\end{array}$ & Statistic & Df & Probability \\
\hline Cross Section F & 8,727556 & $-20,73$ & 0,0000 \\
\hline $\begin{array}{c}\text { Cross Section } \\
\text { Chi Square }\end{array}$ & 128,221553 & 20 & 0,0000 \\
\hline $\begin{array}{c}\text { Cross Section } \\
\text { random }\end{array}$ & 37,528940 & 11 & 0,0001 \\
\hline
\end{tabular}

Sumber: Data Output Eviews

\section{Uji F (Serentak)}

Variabel-variabel independen perlu diuji apakah dapat memberikan pengaruh terhadap variabel dependen secara bersama-sama, maka diperlukan Uji F. Kriteria pengambilan keputusannya yaitu jika signifikansi dari $F$ < 0,05 maka variabel independen secara bersama mempengaruhi variabel dependen, dan sebaliknya. Hasil penelitian menunjukkan bahwa nilai probabilita F-statistic sebesar 0,00 $<0,05$, sehingga keputusan yang diperoleh yaitu $\mathrm{H}_{0}$ ditolak, kesimpulannya adalah variabel independen yaitu kinerja keuangan, struktur modal, dan tata Kelola perusahaan secara bersama-sama berpengaruh terhadap variabel dependen yaitu nilai perusahaan.

\section{Uji Goodness of Fit $\left(R^{2}\right)$}

Fungsi regresi sampel yang digunakan dalam penelitian harus diuji kemampuannya dalam menjelaskan hubungan variabel independen terhadap variabel dependen, makanya diperlukan uji goodness of fit atau yang bisa disebut koefisien determinasi $\left(R^{2}\right)$. Hasil koefisien determinasi memiliki nilai antara 0 sampai dengan 1 . Nilai yang mendekati angka 1 berarti bahwa variable-variabel independen memiliki kemampuan yang besar atau variablevariabel tersebut dapat memberikan hampir semua informasi atas variabel dependen. Sebaliknya, jika nilai $\mathrm{R}^{2}$ nya kecil berarti bahwa variabel-variabel independen memiliki kemampuan yang kecil terhadap variabel dependen.

Hasil uji goodness of fit $\left(\mathrm{R}^{2}\right)$ menunjukkan nilai adjusted $R$ square sebesar 0,25 yang berarti bahwa nilai perusahaan dapat dijelaskan sebesar $25 \%$ oleh variabel bebas yang ada dalam penelitian ini yaitu pertumbuhan penjualan, ROE, ROA, DER, DPR, dewan direksi, kepemilikan institusional, kepemilikan manajerial, komite audit, dewan komisaris, dan komisaris independen. Sisanya senilai $75 \%$ dijelaskan oleh variabel-variabel lain yang terdapat di luar model penelitian ini.

\section{Analisis Statistik Deskriptif}

Uji statistik deskriptif memiliki tujuan yaitu untuk menguji dan menjelaskan karakteristik sampel yang sedang diteliti. Uji ini biasanya memiliki hasil yaitu informasi dalam bentuk tabel yang setidaknya berisi nama variabel yang diteliti, rata-rata, nilai maksimal, nilai minimum, standar deviasi dari variabel tersebut, beserta penjelasan dari isi tabel tersebut.

\section{Uji T (Individu)}

Uji $t$ ini bertujuan untuk menguji pengaruh dari setiap variabel independen terhadap variabel dependen. Kriteria pengambilan keputusannya yaitu jika 
signifikansi dari t hitung $<0,05$ maka $\mathrm{H}_{0}$ ditolak dan sebaliknya.

\section{Hasil dan Pembahasan Analisis Statistik Deskriptif}

Berdasarkan uji analisis statistik deskriptif pada tabel 4 dibawah ini dapat diinterpretasikan sebagai berikut: Tobins Q memiliki nilai rata-rata sebesar 2,993 dan standar deviasi sebesar 2,956. Perusahaan yang memiliki nilai tobins $q$ terbesar senilai 14,415 yaitu PT Unilever Indonesia, Tbk. pada tahun 2020 dan nilai terkecilnya senilai 0,435 dimiliki oleh PT Wismilak Inti Makmur Tbk. pada tahun 2018. Pertumbuhan penjualan memiliki nilai rata-rata yaitu sebesar 0,053 dan standar deviasi sebesar 0,138 . Nilai terbesarnya yaitu 0,504 dimiliki oeh PT Sekar Bumi, Tbk. pada tahun 2020 dan nilai terkecilnya yaitu -0,465 dimiliki oleh PT Multi Bintang Indonesia pada tahun 2020. Return on Equity memiliki nilai rata-rata yaitu sebesar $-2,017$ dan standar deviasi sebesar 1,343. Niai terbesarnya yaitu 0,808 dimiliki oleh PT Merck pada tahun 2018 dan nilai terkecilnya yaitu $-7,344$ dimiiki oleh PT Chintose International Tbk. pada tahun 2020. Return on Asset memiliki nilai rata-rata yaitu sebesar 0,137 dan standar deviasi sebesar 0,135 . Nilai terbesarnya yaitu 0,921 dimiliki oleh PT Merck pada tahun 2018 dan nilai terkecilnya yaitu 0,000 dimiliki oleh Chintose International Tbk. tahun 2020.

Debt to Equity Ratio memiliki nilai ratarata yaitu sebesar 0,709 dan standar deviasi sebesar 0,593. Nilai terbesarnya yaitu 3,159 dimiliki oleh PT Unilever Indonesia, Tbk. pada tahun 2020 dan nilai terkecilnya yaitu 0,083 dimiliki oleh PT Industri Jamu dan Farmasi Sido Muncul, Tbk. pada tahun 2016. Dividend Payout Ratio memiliki nilai rata-rata yaitu sebesar 0.530 dan standar deviasi sebesar 0.641. Nilai terbesarnya yaitu 5,238 yang dimiliki oleh PT Kimia Farma, Tbk. pada tahun 2019 dan nilai terkecilnya yaitu 0,000 dimiliki oleh oleh beberapa perusahaan diantaranya yaitu PT Akasha Wira International, Tbk dan PT Sekar Bumi, Tbk. yang selama periode penelitian yaitu 2016-2020 tidak pernah membagikan dividen.

Dewan direksi memiliki nilai rata-rata yaitu sebesar 6,067 dan standar deviasi yaitu 2,387. Nilai terbesarnya yaitu sebesar 12 dimiliki oleh PT Indofood Sukses Makmur, Tbk pada tahun 2015 hingga 2017 dan nilai terkecilnya yaitu 2 dimiliki oleh PT Akasha Wira International, Tbk tahun 2018 hingga 2020. Kepemilikan Institusional memiliki nilai rata-rata yaitu sebesar 0,764 dan standar deviasi sebesar 0,183 . Nilai terbesarnya yaitu 0,945 dimiliki oleh PT Kimia Farma, Tbk. pada tahun 2018 dan nilai terkecilnya yaitu 0,214 dimiliki oleh PT Ultrajaya Milk Industry \& Trading Company Tbk pada tahun 2020. Kepemilikan manajerial memiliki nilai rata-rata yaitu sebesar 0,049 dan standar deviasi yaitu 0,117 . Nilai terbesarnya yaitu 0.482 dimiliki oleh PT Ultrajaya Milk Industry \& Trading Company Tbk pada tahun 2020 dan nilai terkecilnya yaitu 0,000 dimiliki oleh beberapa perusahaan salah satunya yaitu PT Delta Djakarta, Tbk. tahun 2015 hingga 2020. Komite Audit memiliki nilai rata-rata yaitu sebesar 3,057 dan standar deviasi 0,233. Nilai terbesarnya yaitu 4 dimiliki oleh PT Kimia Farma, Tbk. pada tahun 2015 hingga 2020 dan PT Hanjaya Mandala Sampoerna, Tbk. tahun 2019 dan nilai terkecilnya yaitu 3 dimiliki oleh perusahaan lainnya yang hampir mencakup keseluruhan sampel, salah satunya yaitu PT Nippon Indosari Corporindo, Tbk. Dewan komisaris memiliki nilai rata-rata yaitu sebesar 4,571 dan standar deviasinya yaitu 1,720 . Nilai terbesarnya yaitu 9 dimiliki oleh PT Hanjaya Mandala Sampoerna, Tbk. tahun 2019 dan nilai terkecilnya yaitu 2 dimiliki oleh PT Chitose International, Tbk. tahun 2015 hingga 2019 dan PT Merck tahun 2018 hingga 2020. Komisaris independen memiliki nilai rata-rata yaitu sebesar 0,434 dan standar deviasi 0,134. Nilai terbesarnya yaitu 0,833 dimiliki oleh PT Unilever Indonesia, Tbk. pada tahun 2020 dan nilai terkecilnya yaitu 0,000 dimiliki oleh PT Mayora Indah, Tbk. pada tahun 2019 dan 2020.

Tabel 4

Hasil Uji Statistik Deskriptif

\begin{tabular}{|lrrrr|}
\hline & Minimum & Maximum & Mean & $\begin{array}{l}\text { Std. } \\
\text { Dev. }\end{array}$ \\
\hline TOBINSQ & 0.435 & 14.415 & 2.993 & 2.956 \\
\hline PP & -0.465 & 0.504 & 0.053 & 0.138 \\
\hline LNROE & -7.344 & 0.809 & -2.017 & 1.343 \\
\hline ROA & 0.001 & 0.921 & 0.137 & 0.135 \\
\hline DER & 0.083 & 3.159 & 0.709 & 0.593 \\
\hline DPR & 0.000 & 5.238 & 0.530 & 0.641 \\
\hline DD & 2.000 & 12.000 & 6.067 & 2.387 \\
\hline KINST & 0.214 & 0.945 & 0.764 & 0.183 \\
\hline
\end{tabular}




\begin{tabular}{|lllll|}
\hline KM & 0.000 & 0.482 & 0.049 & 0.117 \\
\hline KA & 3.000 & 4.000 & 3.057 & 0.233 \\
\hline DK & 2.000 & 9.000 & 4.571 & 1.720 \\
\hline KINDP & 0.000 & 0.833 & 0.434 & 0.134 \\
\hline
\end{tabular}

Sumber: Data Output Eviews

\section{Model Regresi Penelitian}

Metode penelitian yang sesuai dengan judul penelitian ini dapat dijabarkan secara sistematis hubungan variabelnya sebagai berikut :

$\mathrm{NP}=9,911+0,242 \mathrm{PP}+0,344 \mathrm{ROE}+$ 2,084ROA + 0,762DER + 0,044DPR - 0,322DD $+5,656 \mathrm{KINST}+5,377 \mathrm{KM}-4,358 \mathrm{KA}+$ 0,945 DK $-1,650$ KINDP $+\mu$

Keterangan :

$\begin{array}{lc}\text { NP } & \text { : Nilai Perusahaan } \\ \text { PP } & \text { : Pertumbuhan Penjualan } \\ \text { ROE } & \text { : Return on Equity } \\ \text { ROA } & \text { : Return on Asset } \\ \text { DER } & \text { : Debt to Equity Ratio } \\ \text { DPR } & \text { : Dividend Payout Ratio } \\ \text { DD } & \text { : Dewan Direksi } \\ \text { KINST } & \text { : Kepemilikan Instritusional } \\ \text { KM } & \quad \text { : Kepemilikan Manajerial } \\ \text { KA } & \text { : Komite Audit } \\ \text { DK } & \text { : Dewan Komisaris } \\ \text { KINDP } & \text { : Komite Independen } \\ \text { a } & \text { : Konstanta } \\ \beta_{1} & \text { : Koefisien Kinerja Keuangan } \\ \beta_{2} & \text { : Koefisien Struktur Modal } \\ \beta_{3} & \text { : Tata Kelola Perusahaan } \\ \mu & \text { : Error }\end{array}$

\section{Uji T (Individu)}

Uji $t$ ini bertujuan untuk menguji pengaruh dari setiap variabel independen terhadap variabel dependen. Jika signifikansi dari $\mathrm{t}$ hitung $<0,05$ maka $\mathrm{H}_{0}$ ditolak; jika signifikansi dari $\mathrm{t}$ hitung $>0,05$ maka $\mathrm{H}_{0}$ diterima. Hasil penelitian tertera pada table 5 dengan interpretasi sebagai berikut:

\section{$\mathrm{H}_{1}$ : Terdapat pengaruh Kinerja Keuangan terhadap Nilai Perusahaan.}

Berdasarkan Hasil dari penelitian pada tabel 5, menyatakan bahwa nilai sig dari pertumbuhan penjualan sebesar 0,819 menyatakan bahwa pertumbuhan penjualan tidak memiliki pengaruh terhadap nilai perusahaan, hasil penelitian ini mendukung penelitian sebelumnya oleh Pantow et al., (2015) yang menunjukkan bahwa pertumbuhan penjualan tidak berpengaruh terhadap nilai perusahaan. Hal ini menunjukkan bahwa pertumbuhan penjualan tidak menaikkan nilai perusahaan. Berdasarkan tabel 5, nilai sig pertumbuhan pendapatan (ROE) sebesar 0,100 yang mengartikan bahwa pertumbuhan pendapatan tidak memiliki pengaruh terhadap nilai perusahaan. Penelitian ini mendukung penelitian sebelumnya oleh Lesmana et al., (2020) yang menyatakan bahwa ROE tidak berpengaruh terhadap nilai perusahaan. $\mathrm{Hal}$ in menunjukkan bahwa pertumbuhan pendapatan tidak menaikkan nilai perusahaan. Dari Haisl tabel 5, nilai sig ROA sebesar 0.257 yang menyatakan bahwa ROA tidak memiliki pengaruh terhadap nilai perusahaan, hal ini sejalan dengan penelitian terdahulu oleh Muchayatin \& Awaliyah, (2019) yang menyatakan bahwa ROA tidak berpengaruh terhadap nilai perusahaan. Artinya pertumbuhan ROA tidak meningkatkan nilai perusahaan. Dari hasil ini dapat disimpulkan bahwa kinerja keuangan yang diukur dengan tiga proksi yaitu pertumbuhan penjualan, pertumbuhan pendapatan, dan ROA tidak ada yang memiliki pengaruh terhadap nilai perusahaan. Hal ini tidak sejalan dengan penelitian yang dilakukan oleh Talwar, (2020) yang menyatakan bahwa kinerja keuangan yang diukur dengan tiga proksi yaitu pertumbuhan penjualan, pertumbuhan pendapatan, dan ROA memiliki pengaruh terhadap nilai perusahaan. Sehingga dari penelitian ini diketahui bahwa meningkatnya kinerja keuangan tidak dapat menaikkan nilai perusahaan.

\section{$\mathrm{H}_{2}$ : Terdapat Pengaruh Struktur Modal terhadap Nilai Perusahaan}

Hasil dari penelitian pada tabel 5, menyatakan bahwa nilai sig leverage (DER) sebesar 0,110 sehingga variabel leverage (DER) tidak memiliki pengaruh signifikan terhadap nilai perusahaan, sedangkan nilai sig Dividen Payout Ratio (DPR) sebesar 0,866 yang mengartikan bahwa DPR tidak memiliki pengaruh signifikan terhadap nilai perusahaan. Kedua proksi variabel ini memiliki hasil bahwa tidak terdapat pengaruh, sehingga dalam 
penelitian ini struktur modal tidak memiliki pengaruh signifikan terhadap nilai perusahaan. Penelitian ini mendukung penelitian sebelumnya oleh (Irawan \& Nurhadi, 2019) yang mengatakan bahwa struktur modal tidak berpengaruh terhadap nilai perusahaan. Penambahan utang dalam struktur modal dapat mengurangi penggunaan saham sehingga meminimalisasi biaya keagenan ekuitas, namun perusahaan jadi memiliki kewajiban untuk mengembalikan pinjaman dan beban bunga secara periodik. Utang menimbulkan beban bunga tetap yang tidak melihat besarnya pendapatan. Semakin tinggi utang, maka bunga utang akan meningkat lebih tinggi dari penghematan pajak sehingga kebijakan manajemen dalam menggunakan utang berpengaruh negative dan signifikan terhadap nilai perusahaan. Hal ini tidak sejalan dengan penelitian yang dilakukan oleh Talwar, (2020) yang menyatakan bahwa struktur modal berpengaruh positif terhadap nilai perusahaan.

\section{$\mathrm{H}_{3}$ : Terdapat Pengaruh Tata Kelola Perusahaan terhadap Nilai Perusahaan}

Hasil penelitian pada tabel 5 menunjukkan bahwa nilai sig dewan direksi (DD) sebesar 0,021<0,05 artinya dewan direksi memiliki pengaruh signifikan terhadap nilai perusahaan. Penelitian ini mendukung penelitian sebelumnya oleh Sondokan et al., (2019) menunjukkan bahwa pengaruh dewan direksi terhadap nilai perusahaan signifikan. Hasil tersebut juga mendukung hasil penelitian sebelumnya yang dilakukan oleh Talwar (2020) yang mengatakan bahwa govscore berpengaruh terhadap nilai perusahaan. Berdasarkan tabel 5, nilai sig kepemilikan institusional (KINST) sebesar 0,045 $<0,05$ artinya kepemilikan institusional memiliki pengaruh terhadap nilai perusahaan. Nilai sig menurut tabel 5 kepemilikan manajerial (KM) sebesar 0,151 sehingga struktur kepemilikan tidak memiliki pengaruh terhadap nilai perusahaan. Hasil ini mendukung penelitian sebelumnya dari Dewi \& Sanica, (2014) yang menyatakan bahwa kepemilikan manajerial tidak berpengaruh terhdap nilai perusahaan. Hal ini menyimpulkan bahwa kepemilikan saham oleh direksi, manajemen, komisaris maupun pihak lain yang terlibat dalam perusahaan tidak akan menaikkan nilai perusahaan. Nilai sig komite audit (KA) sebesar $0,000<0,05$ artinya HO ditolak sehingga komite audit memiliki pengaruh terhadap nilai perusahaan. Menurut tabel 5 nilai sig dewan komisaris (DK) sebesar 0,000 0,05 artinya dewan komisaris memiliki pengaruh terhadap nilai perusahaan. Penelitian ini mendukung penelitian sebelumnya oleh Fiadicha \& Hanny, (2016) yang menyatakan bahwa terdapat pengaruh signifikan antara dewan komisaris dengan nilai perusahaan, di mana semakin besar board size, semakin tinggi nilai perusahaan. Nilai sig komisaris independen (KINDP) berdasarkan tabel 5 sebesar 0,378 artinya komisaris independen tidak memiliki hubungan terhadap nilai perusahaan. Hal ini menyatakan bahwa keberadaan dewan komisaris independen dalam suatu perusahaan tidak akan menaikkan nilai perusahaan. Penelitian ini mendukung penelitian sebelumnya dari Kumayas et al., (2018) yang menyatakan bahwa dewan komisaris independent tidak berpengaruh terhadap nilai perusahaan.

Tabel 5

Uji T (Individu)

\begin{tabular}{|cccc|}
\hline \multirow{2}{*}{$\begin{array}{c}\text { Variabel } \\
\text { Independen }\end{array}$} & \multicolumn{3}{c|}{ Variabel Dependen } \\
\cline { 2 - 4 } & \multicolumn{3}{c|}{ Coefficient of Variation } \\
\hline Koefisien & Probabilitas & Kesimpulan \\
\hline $\begin{array}{c}\text { Pertumbuhan } \\
\text { Penjualan }\end{array}$ & 9,911 & - & - \\
\hline $\begin{array}{c}\text { Pertumbuhan } \\
\text { Pendapatan }\end{array}$ & 0,242 & 0,819 & $\begin{array}{c}\text { Tidak } \\
\text { Signifikan }\end{array}$ \\
\hline ROA & 2,084 & 0,257 & $\begin{array}{c}\text { Tidak } \\
\text { Signifikan }\end{array}$ \\
\hline Teverage & 0,762 & 0,110 & $\begin{array}{c}\text { Tignifak } \\
\text { Tidak }\end{array}$ \\
\hline $\begin{array}{c}\text { Sivnifikan } \\
\text { Payout Ratio }\end{array}$ & 0,044 & 0,866 & $\begin{array}{c}\text { Tidak } \\
\text { Signifikan }\end{array}$ \\
\hline $\begin{array}{c}\text { Dewan } \\
\text { Direksi }\end{array}$ & $-0,322$ & 0,021 & $\begin{array}{c}\text { Negatif } \\
\text { Signifikan }\end{array}$ \\
\hline $\begin{array}{c}\text { Kepemilikan } \\
\text { Institusional }\end{array}$ & 5,656 & 0,045 & $\begin{array}{c}\text { Positif } \\
\text { Signifikan }\end{array}$ \\
\hline $\begin{array}{c}\text { Kepemilikan } \\
\text { Manajerial }\end{array}$ & 5,377 & 0,151 & $\begin{array}{c}\text { Tidak } \\
\text { Signifikan }\end{array}$ \\
\hline Komite Audit & $-4,358$ & 0,000 & $\begin{array}{c}\text { Negatif } \\
\text { Signifikan }\end{array}$ \\
\hline $\begin{array}{c}\text { Dewan } \\
\text { Komisaris }\end{array}$ & 0,945 & 0,000 & $\begin{array}{c}\text { Positif } \\
\text { Signifikan }\end{array}$ \\
\hline $\begin{array}{c}\text { Komisaris } \\
\text { Independen }\end{array}$ & $-1,650$ & 0,378 & $\begin{array}{c}\text { Tidak } \\
\text { Signifikan }\end{array}$ \\
\hline
\end{tabular}

Sumber: Data Output Eviews 


\section{Simpulan}

Berdasarkan hasil penelitian yang telah dilakukan, maka dapat ditarik kesimpulan sebagai berikut:

1. Kinerja keuangan yang diukur menggunakan tiga proksi yaitu pertumbuhan penjualan, pertumbuhan pendapatan, dan ROA diketahui bahwa tidak ada yang memiliki pengaruh signifikan terhadap nilai perusahaan.

2. Struktur modal yang diukur dengan proksi leverage dan dividen payout ratio tidak memiliki pengaruh signifikan terhadap nilai perusahaan.

3. Tata kelola perusahaan yang diukur dengan proksi dewan direksi, kepemilikan institusional, kepemilikan manajerial, komite audit, dewan komisaris, dan komisaris independen, ada 4 proksi yang memiliki pengaruh terhadap nilai perusahaan, yaitu dewan direksi, kepemilikan institusional, komite audit, dan dewan komisaris, sedangkan untuk kepemilikan manajerial, dan komisaris independen tidak memiliki pengaruh terhadap nilai perusahaan.

\section{Implikasi}

Berdasarkan hasil penelitian ini, terdapat beberapa manfaat yang dapat diambil sebagai implikasi manajer keuangan guna dijadikan pertimbangan dalam pengambilan keputusan perusahaan dalam melakukan kebijakan dan pertimbangan, juga bagi para investor. Beberapa implikasi tersebut adalah sebagai berikut:

a. Bagi perusahaan

Manajer perusahaan harus menerapkan manajemen yang terbaik di dalam perusahaan. Hal tersebut bisa dilakukan jika perusahaan memiliki dewan komisaris, karena meningkatnya jumlah dewan komisaris dalam perusahaan akan meningkatkan nilai perusahaan. Dengan adanya dewan komisaris, pengawasan dan kontrol terhadap perusahaan dapat dilakukan lebih efektif dan efisien, juga dapat memberikan nasihat atau pendapat saat dewan direksi mengambil sebuah keputusan perusahaan. Manajer juga harus memperhatikan porsi kepemilikan saham perusahaan, dimana kepemilikan institusional harus jauh lebih tinggi dari kepemilikan manajerial. Hal tersebut akan mengurangi konflik keagenan dan informasi asimetris dalam perusahaan, karena para manajer tidak mengambil keuntungan dari jabatan dan informasi yang dimilikinya di perusahaan tersebut, sehingga kepercayaan investor akan meningkat dan juga meningkatkan nilai perusahaan. Hal lainnya yang perlu diperhatikan oleh manajer adalah mengurangi jumlah dewan direksi dan komite audit agar dapat meningkatkan nilai perusahaan.

b. Bagi Investor

Pemilihan perusahaan untuk berinvestasi harus dilihat dari berapa prosentase kepemilikan institusional nya, semakin tinggi kepemilikan institusional maka perusahaan tersebut dapat dikatakan semakin baik. Kepemilikan manajerial yang tinggi patut diwaspadai karena bisa saja terjadi konflik keagenan dan informasi asimetris dimana para manajer yang memiliki saham pada perusahaan tempat ia bekerja lebih mementingkan keuntungan dari saham yang dimilikinya daripada kewajibannya pada perusahaan. Penilaian lainnya yang dapat dilakukan oleh investor yaitu dari jumlah dewan direksi yang dimiliki oleh perusahaan. Perusahaan yang memiliki jumlah dewan direksi yang banyak, akan meningkatkan nilai perusahaan. Investor juga harus memilih perusahaan yang memiliki jumlah komite audit dan dewan direksi dengan jumlah sedikit agar nilai perusahaan meningkat. Kesimpulannya adalah para investor harus memilih perusahaan yang memiliki tata kelola perusahaan yang baik, yang akan meningkatkan nilai perusahaan.

\section{Keterbatasan dan Saran}

Berdasarkan hasil penelitian yang telah dilakukan, dalam penelitian ini terdapat keterbatasan pada variabel bebas penelitian ini yakni, kinerja keuangan, struktur modal, dan tata kelola perusahaan yang dinilai masih kurang dalam menjelaskan faktor yang mempengaruhi nilai perusahaan sehingga dapat menyebabkan kurang efektif nya data yang dihasilkan. Saran yang dapat disampaikan kepada penelitian di masa depan adalah, 
menambah variabel penelitian sehingga penelitian dapat menghasilkan data yang dapat mengintepretasikan nilai perusahaan secara keseluruhan. Salah satu variabel yang bisa ditambahkan yaitu tax avoidance dan ukuran perusahaan yang didukung oleh penelitian Nerisse \& Raisa, (2021) yang mengatakan bahwa tax avoidance dan ukuran perusahaan berpengaruh pada nilai perusahaan.

\section{Daftar Pustaka}

Alamsyah, A. R., \& Muchlas, Z. (2018). Pengaruh Struktur Kepemilikan, Struktur Modal, Dan Ios Terhadap Nilai Perusahaan Dengan Kebijakan Dividen Sebagai Variabel Intervening Pada Perusahaan Manufaktur Terdaftar Di Bei. Jurnal IImiah Bisnis Dan Ekonomi Asia, 12(1), 9-16. https://doi.org/10.32812/jibeka.v12i1.5

Arifianto, M., \& Chabachib, M. (2016). Analisis Faktor-Faktor yang Mempengaruhi Nilai Perusahaan (Studi Kasus Pada Perusahaan yang Terdaftar pada Indeks LQ-45 Periode 2011-2014). Diponegoro Journal Of Management, 5(1), 1-12. http://ejournal-

s1.undip.ac.id/index.php/dbr

Asiri, B. K., \& Hameed, S. A. (2014). Financial Ratios and Firm's Value in the Bahrain Bourse. Research Journal of Finance and Accounting, 5(7), 1-10. https://iiste.org/Journals/index.php/RJF A/article/view/12297

Dewi, K. R. C., \& Sanica, I. G. (2014). Pengaruh Pengungkapan Corporate Social Responsibility, Profitabilitas, Dan Kepemilikan Manajerial Terhadap Nilai Perusahaan Pada Perusahaan Manufaktur Yang Terdaftar Di Bursa Efek Indonesia Tahun 2008-2012. Jurnal Riset Mahasiswa Akuntansi Unikama, 2(2).

Fiadicha, F., \& Hanny, R. Y. (2016). Good corporate governance, corporate social responsibility. Jurnal Akuntansi Manajerial, 1(1), 22-45. http://journal.uta45jakarta.ac.id/index.p hp/JAM/article/view/737

Gayatri, N., \& Mustanda, I. (2014). Pengaruh Struktur Modal, Kebijakan Dividen Dan Keputusan Investasi Terhadap Nilai Perusahaan. E-Jurnal Manajemen Universitas Udayana, 3(6), 249699.

Hunardy, N., \& Tarigan, J. (2017). Pengaruh Kepemilikan Pemerintah Terhadap Kinerja Keuangan Melalui Dewan Komisaris Independen Sebagai Variabel Intervening. Business Accounting Review, 5(2), 602-604. http://publication.petra.ac.id/index.php/ akuntansi-bisnis/article/view/6636

Irawan, D., \& Nurhadi, K. (2019). Pengaruh struktur modal, dan ukuran perusahaan terhadap nilai perusahaan. Jurnal Aktual STIE Trisna Negara, 4(2), 358-372. https://stietrisnanegara.ac.id/jurnal/inde x.php/aktual/article/view/34

Jamaluddin, J., Hermanto, S. B., \& Fidiana, F. (2020). Mekanisme Corporate Governance Terhadap Nilai Perusahaan Dengan Enterprise Risk Management Sebagai Variabel Intervening. Wahana: Jurnal Ekonomi, Manajemen Dan Akuntansi, 23(1), 59-80. https://doi.org/10.35591/wahana.v23i1. 185

Kristie Onasis, R. (2016). Pengaruh Tata Kelola Perusahaan terhadap Nilai Perusahaan pada Perusahaan Sektor Keuangan yang Terdaftar di BEI. Bina Ekonomi, 20(1), $1-22$.

https://doi.org/10.26593/be.v20i1.1893. $1-22$

Kumayas, N. D., Pangemanan, S., \& Alexander, S. (2018). Pengaruh Arus Kas Operasi Dan Pertumbuhan Penjualan Terhadap Harga Saham Pada Perusahaan Indeks Lq45 Yang Terdaftar Di Bursa Efek Indonesia Tahun (2012-2016). Going Concern: Jurnal Riset Akuntansi, 13(02), 659-667. 
Jurnal Ekonomi : Journal of Economic

p-ISSN 2087-8133| e-ISSN : 2528-326X

https://doi.org/10.32400/gc.13.02.1992 6.2018

Lesmana, T., Iskandar, Y., \& Heliani. (2020). Pengaruh Kinerja Keuangan Terhadap Nilai Perusahaan pada Perusahaan Rokok Yang Terdaftar di Bei. Jurnal Proaksi, 2(1). https://doi.org/10.37751/parameter.v4i1 .31

Marini, Y., \& Marina, N. (2017). Pengaruh Good Corporate Governance Terhadap Nilai Perusahaan (Studi Empiris Pada Perusahaan Manufaktur yang Terdaftar di Bursa Efek Indonesia). Jurnal Humaniora, 1(1), 7-20.

Muchayatin, \& Awaliyah, A. (2019). Analisis Nilai Perusahaan Perbankan Yang Terdaftar Di Bei Tahun 2017. Jurnal IImiah UNTAG Semarang, 2(2), 221230.

Mustikowati, R. I., \& Haryanto, S. (2019). Pengaruh Good Corporate Governance Terhadap Nilai Perusahaan. Jurnal Humaniora: Jurnal IImu Sosial, Ekonomi Dan Hukum, 1(1), 7-20. https://doi.org/10.30601/humaniora.v1i 1.37

Nerisse, A., \& Raisa, P. (2021). Pengaruh Profitabilitas, Tax Avoidance, Leverage, dan Ukuran Perusahaan Terhadap Nilai Perusahaan (Studi Empiris Pada Perusahaan Manufaktur yang Terdaftar di BEI Tahun 2013-2016). Jurnal Ilmiah Akuntansi Kesatuan, 9(1), 31-40. https://doi.org/10.37641/jiakes.v9i1.436

Nursani, E. (2020). Pengaruh Kinerja Keuangan Terhadap Nilai Perusahaan Dengan Csr Sebagai Variabel Moderasi. AKTIVA Jurnal Akuntansi Dan Investasi, 5(1), 29-44.

http://publication.petra.ac.id/index.php/ manajemen-keuangan/article/view/2961

Pantow, M. S., Murni, S., \& Trang, I. (2015). Analisa Pertumbuhan Penjualan, Ukuran Perusahaan, Return on Asset, Dan
Struktur Modal Terhadap Nilai Perusahaan Yang Tercatat Di Indeks Lq 45. Jurnal Riset Ekonomi, Manajemen, Bisnis Dan Akuntansi, 3(1), 961-971. https://doi.org/10.35794/emba.v3i1.780 1

Permatasari, \& Azizah. (2018). Pengaruh Struktur Modal Terhadap Nilai Perusahaan (Studi Pada Perusahaan Sub Sektor Makanan Dan Minuman Yang Terdaftar Di Bursa Efek Indonesia Tahun 2013-2016). Jurnal Administrasi Bisnis, 61(4), 100-106. http://administrasibisnis.studentjournal. ub.ac.id/index.php/jab/article/view/2628

Ramadhani, R., Akhmadi, \& Kuswantoro, M. (2018). Pengaruh Leverage Dan Profitabilitas Terhadap Nilai Perusahaan Dengan Kebijakan Dividen Sebagai Variabel Intervening. Jurnal Riset Bisnis Dan Manajemen Tirtayasa, 2(1), 21-42.

Ramadhani, R., Akhmadi, \& Kuswantoro, M. (2018). Pengaruh leverage dan profitabilitas terhadap nilai perusahaan dengan kebijakan dividen sebagai variabel intervensi pada indeks BEI 30 yang tercantum di bursa efek indonesia. Jurnal Manajemen Sains Dan Organisasi, 1(2), 124-138. https://doi.org/10.52300/jmso.v1i2.2379

Sakti, I. (2018). Analisis Regresi Data Panel Menggunakan Eviews. Modul Eviews 9, 1-25.

https://www.academia.edu/37059747/A NALISIS_REGRESI_DATA_PANEL_MENG GUNAKAN_EVIEWS

Sondokan, N. V, Koleangan, R. A., \& Karuntu, M. M. (2019). Pengaruh Dewan Komisaris Independen, Dewan Direksi, Dan Komite Audit Terhadap Nilai Perusahaan Yang Terdaftar Dibursa Efek Indonesia Periode 2014-2017. Jurnal EMBA: Jurnal Riset Ekonomi, Manajemen, Bisnis Dan Akuntansi, Л4), 5821-5830.

https://doi.org/10.35794/emba.v7i4.265 17 
Sutrisno, S. (2016). Struktur modal: Faktor penentu dan pengaruhnya pada nilai perusahaan. Jurnal Siasat Bisnis, 20(1), 79-89.

https://doi.org/10.20885/jsb.vol20.iss1. art7

Talwar, S. (2020). Dynamics of Firm Value, Financial Performance, Leverage, and Governance: A Panel Data Analysis of Listed Indian Firms. International Journal of Business \& Economics, 19(2), 131-149. http://140.134.131.16/table of content/pdf/vol19-2/01.pdf

Tikawati, T. (2016). Pengaruh Corporate Governance, Growth Opportunity dan Net Profit Margin (NPM) Terhadap Nilai Perusahaan (Studi Empiris pada Perusahaan Go Public di Bursa Efek Indonesia Tahun 2008-2011). Al-Tijary, 1(2), 121-140. https://doi.org/10.21093/at.v1i2.528

Tunggal, C. A., \& Nagatno. (2018). Pengaruh Struktur Modal Terhadap Nilai Perusahaan Dengan Ukuran Dan Umur Perusahaan Sebagai Variabel Moderator (Studi Kasus Tahun 2014- 2016) Pada Perusahaan Sub-Sektor Makanan Dan Minuman Yang Terdaftar Di Bei. Jurnal IImu Administrasi Bisnis, 72), 141-157. https://ejournal3.undip.ac.id/index.php/j iab/article/view/20330

Utami, I. (2017). Pengaruh Struktur Modal Terhadap Nilai Perusahaan (Studi Kasus Terhadap Sub Sektor Perdagangan Eceran Yang Terdaftar di BEI Tahun 2011-2015) Indri. Journal of Chemical Information and Modeling, 8(9), 1-58. https://doi.org/https://doi.org/10.36555 /jasa.v3i3.1273

Wibowo, S. (2015). Pengaruh Komisaris Independen, Komite Audit, Pada Perbankan Yang Terdaftar Di Bursa Efek Indonesia 2011 - 2015 (Studi Kasus: Top 10 Perbankan Terbaik Di Indonesia). Prosiding Seminar Nasional and Call for Papers "Tantangan Pengembangan IImu Akuntansi, Inklusi
Keuangan, Dan Kontribusinya Terhadap Pengembangan Ekonomi Berkelanjutan," 84-102.

http://digilib.mercubuana.ac.id/manager /t!@file_artikel_abstrak/Isi_Artikel_9596 35099090.pdf 